\title{
Assessment of transportation stress in Dromedary camel (Camelus dromedarius) by using behavioural and physiological measures
}

\author{
H.H Emeash ${ }^{* 1}$; A.S Mostafa ${ }^{2}$; M. Karmy ${ }^{4}$; Fatma Khalil ${ }^{1}$; Mohamed Z. Elhussiny ${ }^{3}$ \\ ${ }^{l}$ Department of Animal_Behaviour, Management and Development of Animal Wealth, Faculty of Veterinary Medicine, \\ Minia University, Minia, Egypt. \\ ${ }^{2}$ Department of Behaviour, Management and Development of Animal Wealth, Faculty of Veterinary Medicine, Minia \\ University, Egypt. \\ ${ }^{3}$ Department of Animal Behaviour and Management, Faculty of Veterinary Medicine, Aswan University, Aswan, Egypt. \\ ${ }^{4}$ Department of Food Hygiene, Faculty of Veterinary Medicine, Aswan University, Aswan, Egypt.
}

*Corresponding author’s E-mail: hhemeash@yahoo.com

\begin{abstract}
Transportation is often considered as one of the main causes of stress raising considerable interest, both in animal welfare and economic fields. Stressful transportation of camel may cause severe welfare consequences and economic losses. Therefore, this study was conducted to assess the stress resulting from transportation of Dromedary Camel (Camelus dromedarius) by measuring some behavioural and physiological responses. Camels were imported from Dongola quarantine in Sudan to Arqueen (at the borders between Egypt and Sudan) by walking for about $450 \mathrm{~km}$. After that, camels are transported from Arqueen to Abu Simble quarantine in Aswan. According to method of transportation, camels were randomly assigned into three groups; group 1 (camels were transported by trucks for about $150 \mathrm{~km}$, taking about 2-3 h), group 2 (camels were transported by walking for about $90 \mathrm{~km}$, lasting for about $24 \mathrm{~h}$ ), and group 3 (non-transported camels). In Abu Simble quarantine, 30 healthy males (5-7 years and 300-400 kg b.wt.) were selected for each group (three replicates for each). Some behaviours were selected from the ethogram and are used in the analysis which include comfort (recumbency and standing), ingestive (feeding and rumination), eliminative (defecation and urination) and body care (rubbing, scratching and nipping). All behaviours were recorded in the morning and afternoon by direct personal observation for $60 \mathrm{~min}$ with an interval of $5 \mathrm{~min}$ and calculated as a frequency per total observation time. Furthermore, blood samples were collected just after arrival of camels (T0) and at $18 \mathrm{~h}$ after arrival (T18) for hematological examination (PCV\%, total RBCs and WBCs) and measurement of some blood parameters including total protein, albumin, globulin, glucose and cortisol. The results revealed that the frequency of standing, feeding, defecation, urination, scratching and total body care behaviours, were significantly decreased in group $1(81.24,33.51,6.48,9.12,3.87$ and 12.80) and group 2 (10.80, 31.67, $1.40,2.19,1.25$ and 10.96) including transported camels in comparison to control group (97.26, 47.62, 12.16, 16.44, 12.88 and 21.06) respectively. The frequency of recumbancy was increased in transported groups as compared to control one. The results of haematological examination indicated that there is a significant increase in PCV\% and neutrophil count and a significant decrease in lymphocyte count in groups 1 and 2 as compared to control one. Camels transported by trucks had a significant high level of cortisol at T0 $(17.21 \mu \mathrm{g} / \mathrm{dl})$ and $\mathrm{T} 18(6.14 \mu \mathrm{g} / \mathrm{dl})$ in comparison to other groups. In conclusion, transportation of camels either by trucks or walk imposes a marked stress upon them as indicated by behavioural and physiological measures.
\end{abstract}

Keywords: Behaviour, camels, haematology, Stress, Transportation.

\section{INTRODUCTION}

Dromedary camel (Camelus dromedarius) is one of the most important domestic animals in the arid and semiarid regions as it is equipped to produce high quality food at comparatively low costs under extremely harsh environments (Yagil, 1982; Yousif and Babiker, 1989). It can survive well on sandy

\section{Original Article:}

Received $10 \mathrm{Jul} .2016$

Accepted 17 Sept. 2016

Published 14 Oct. 2016 terrain with poor vegetation and may chiefly consume feeds unutilized by other domestic species (Shalah, 1983).

The increasing demand in proteins to feed the ever-growing world population has necessitated the industrialization and transportation of livestock using different means of transportation across several 
ecological zones with different climatic conditions (Minka and Ayo, 2010). Transportation is often considered as one of the main causes of stress raising a considerable interest, both in animal welfare and economic terms (Saeb et al., 2010). Long term transportation of animals by walking or trucks may induce severe stress such as removal from the home environment, loading and unloading, confinement, fasting, water deprivation, social mixing, forced physical exercise, handling, noise and vibration (Warris 1990 and Grigor et al 2001). In addition, transportation stress may reduce animal fitness by inducing dysfunctions of the pituitary, adrenal and thyroid glands (Hartung, 2003). Thus, the resulted stress might have deleterious effects on health, welfare, performance and product quality of farm animals (Borell, 2000).

The adjustment to stress induces a broad range of behavioural, physiological and neuroendocrine changes to allow for a rapid recovery or adaptation to the change (Borell, 2000). Behavioural and physiological measures are widely used as indicators of stress (Grandin, 1993; Mason and Mendl 1993; Fraser and Broom, 1990). Behavioural changes are often recorded as the first sign of distress (Ayo et al., 2002). Normal maintenance behaviours such as ingestive, comfort and body care are necessary for survival of animals (Fraser and Broom, 1990). Therefore, alterations of these behaviours may lead to welfare problems and economic losses in livestock animals. Red and white blood cell counts, blood glucose and plasma cortisol can be used as indicators for short term stress problems such as transportation of camel (Zapata et al., 2004; El Khasmi et al., 2013).

The objective of this study was to assess the stress resulting from transportation of camels by using some behavioural measures including comfort, ingestive, eliminative, body care and aggressive behaviour; and physiological measures including some haematological work and blood levels of proteins, glucose and cortisol.

\section{MATERIALS AND METHODS}

\section{Animals and transportation}

Camels were imported from Dongla quarantine in Sudan to Arqueen (at the borders between Egypt and Sudan) walking for about $450 \mathrm{~km}$. Then after, the camels are moved from Arqueen to Abu Simble quarantine in Egypt as shown in Figure (1). According to the method of transportation, camels were randomly assigned into 3 groups. Group 1(G1) included camels which are transported by truck (they traveled about $150 \mathrm{~km}$, taking about 2-3 h) between mountains. In group 2 (G2) camels are transported by walking for about $90 \mathrm{~km}$ for $24 \mathrm{~h}$ and group 3 (G3) included camels which are not transported and took sufficient rest (control). Camels stay in Abu Simble quarantine for $24 \mathrm{~h}$, during it 30 healthy males (5-7 years and $300-400 \mathrm{~kg}$ body weight) were selected from each group (three replicates for each) which are subjected for behavioural and physiological investigations.

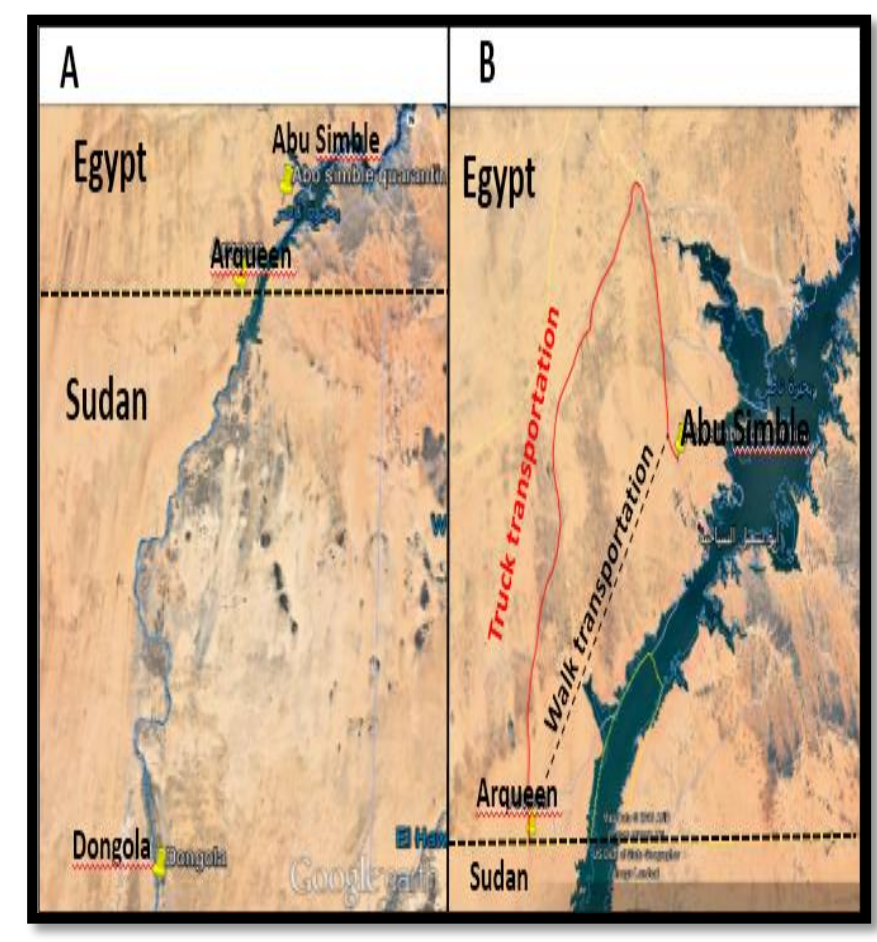

Figure 1: (A) Transportation of camels from Dongla (in Sudan) to Egypt (Aqreem and Abo Simble quarantine). (B) Transportation of camel by walking in Egypt ( from Aqreem and Abo Simble quarantine).

\section{Behaviour recording}

After camel arrival, selected camels are subjected to behavioural recording of some behaviours relevant to transportation stress including comfort (recumbency and standing), ingestive (feeding and rumination), eliminative (defecation and urination) and body care (rubbing, scratching and nipping) by direct personal observation for $60 \mathrm{~min}$ with an interval of 5 min in two periods separated by approximately 12 hours interval according to arrival time (morning and repeated in the afternoon) using scan sampling method with an instantaneous time recording technique by noticing whether a behavior is occurring at the sample point which can be used to determine the proportion of each behaviour frequency an animal spends doing (Martin and Bateson, 1995). 


\section{Physiological investigations Blood Sampling}

Blood samples are collected from ten healthy male camels randomly chosen from each group just after arrival of camels (T0) and at $18 \mathrm{~h}$ after arrival (T18) (kannan, 2000). Three blood samples are collected by jugular venipuncture into three vacutainer tubes, the first containing EDTA for hematological work (PCV\%, Total RBCS, total WBCS), the second without anticoagulant for serum separation, and the third containing sodium fluoride as anticoagulant for determination of glucose in plasma. Serum and plasma samples are collected after separation by Pasteur pipette into clean and dry Eppendorf tubes and kept in deep freezer at $-20^{\circ} \mathrm{C}$ till assayed.

\section{Haematological work}

Red blood cell and WBCs count was performed by using an improved Neubauer chamber and calculated according to the standard method described by Jain (1986). Differential leukocytic count was determined by using "Battlement method" described by Schalm et al. (1975). Furthermore, PCV $\%$ was determined by the microhaematocrit centrifugation technique (Jain, 1986).

\section{Blood assay}

A standard colourimetric method depending on enzymatic reaction is used for determination of total proteins (Weissman, 1950), albumin (Bartholomew and Delaney, 1964) and glucose (Zilva and Pannall, 1979), while globulin concentration was determined by calculation. Cortisol concentration was determined by competitive colorimetric immunoenzymatic method (Burtis and Ashweed, 1994).

\section{Statistical analysis}

The obtained results were analyzed by one way ANOVA using SPSS for Windows (Release 20.0 standard version, IBM Corporation, Chicago, Illinois). The differences were considered statistically significant when $\mathrm{P}<0.05$.

\section{RESULTS}

\section{Behavioural measures}

The behavioural measures including comfort, ingestive, eliminative and body care which are used for assessment of transportation stress are illustrated in Table (1). Concerning comfort behaviour, there was a significant $(p<0.01)$ increase in the time budget of standing behaviour and decrease in the time budget of recumbency behaviour in control group (G3) of camels (97.26 and 2.74) as compared to (G1) truck transported camels (81.24 and 18.76) and (G2) walk transported (10.80 and 89.20) respectively. With regard to ingestive behaviour, there was a significant $(p<0.01)$ increase in the time budget of feeding behaviour in G3 (47.62) in comparison with G1 (33.51) and G2 (31.67), while the time budget of ruminating behaviour was significantly decreased in G3 (2.31) in comparison with G1 (19.72) and G2 (26.72). Referring to eliminative behaviour, the time budget of defecation and urination were significantly decreased in G1 (6.48 and 9.12), and G2 (1.40 and 2.19) as compared to G3 (12.16 and 16.44). Shifting to body care behaviour, the time budget of scratching behaviour was significantly $(p<0.01)$ increased in G3 (12.88) when compared with G1 (3.87) and G2 (1.25). Moreover, the total body care activities were significantly increased in G3 (21.06) as compared with G1 (12.80) and G2 (10.96).

\section{Haematological measures}

The haematological measures used for assessment of transportation stress are shown in Table (2). Transported camels have a significant $(p<0.01)$ high value of PCV at T0 (38.18 and 38.06\%) and T18 (39.70 and 35.76\%) for G1 (truck transport) and G2 (walk transport). Transportation stress caused a significant decrease in RBCs count in G2 at T0 $\left(7.60 \times 10^{6} \mu \mathrm{l}\right)$ and $\mathrm{T} 18 \quad\left(7.71 \times 10^{6} \mu \mathrm{l}\right)$ vs. G1 $\left(8.67 \times 10^{6} \mu \mathrm{l}\right.$ and $\left.8.29 \times 10^{6} \mu \mathrm{l}\right)$ and G3 $\left(8.64 \times 10^{6} \mu \mathrm{hl}\right.$ and $\left.8.59 \times 10^{6} \mu \mathrm{l}\right)$ respectively. Moreover there was a significant decrease in WBCs count in G2 at T0 $\left(12.93 \times 10^{3} \mu \mathrm{l}\right)$ and $\mathrm{T} 18\left(12.94 \times 10^{3} \mu \mathrm{l}\right)$ in comparison to G1 $\left(20.72 \times 10^{3}, \mu 1\right.$ and $\left.16.43 \times 10^{3}, \mu 1\right)$ and G3 $\left(21.73 \times 10^{3}, \mu \mathrm{l}\right.$ and $\left.18.3010^{3} \mu \mathrm{\mu l}\right)$ respectively. A significant increase in neutrophil count was observed in G1 of camels at T0 $\left(14.32 \times 10^{3} \mu \mathrm{l}\right)$ and $\mathrm{T} 18$ $\left(11.33 \times 10^{3} \mu \mathrm{l}\right)$ vs. G2 and G3. On the other hand lymphocyte count was significantly $(p<0.01)$ decreased in G1 $\left(5.18 \times 10^{3} \mu \mathrm{l}\right.$ and $\left.4.10 \times 10^{3} \mu \mathrm{l}\right)$ and $\mathrm{G} 2$ $\left(3.62 \times 10^{3}, \mu \mathrm{l}\right.$ and $\left.3.90 \times 10^{3} \mu \mathrm{l}\right)$ as compared to G3 $\left(7.16 \times 10^{3}, \mu \mathrm{l}\right.$ and $\left.6.92 \times 10^{3} \mu \mathrm{l}\right)$ at T0 and T18 respectively.

\section{Blood measures}

The results concerning the use of some blood measures are illustrated in Table (3). The levels of total proteins, albumin and globulin were variable but in general camels in G1 and G2 had higher values of total proteins, albumin and globulin than those in G3. Moreover, glucose level was significantly decreased in transported camels which is more apparent in G2 at T0 (88.42 $\mathrm{mg} / \mathrm{dl})$ and $\mathrm{T} 18(99.24 \mathrm{mg} / \mathrm{dl})$. Referring to cortisol level, camels transported by trucks (G1) had a significant higher levels at T0 $(17.21 \mu \mathrm{g} / \mathrm{dl})$ at T18 $(6.14 \mu \mathrm{g} / \mathrm{dl})$ than camels in G2 and G3. 
Table 1. Assessment of transportation stress in camels by using behavioural measures

\begin{tabular}{|c|c|c|c|c|c|c|c|c|c|c|}
\hline \multirow{2}{*}{ Groups } & \multicolumn{2}{|c|}{ Comfort behaviour } & \multicolumn{2}{|c|}{$\begin{array}{l}\text { Ingestive } \\
\text { behaviour }\end{array}$} & \multicolumn{2}{|c|}{$\begin{array}{c}\text { Eliminative } \\
\text { behaviour }\end{array}$} & \multicolumn{4}{|c|}{ Body care behaviour } \\
\hline & Standing & Recumbency & $\begin{array}{c}\text { Feedin } \\
\mathrm{g}\end{array}$ & Rumination & Defecation & Urination & $\begin{array}{c}\text { Rubbin } \\
\mathrm{g}\end{array}$ & Scratching & Nipping & $\begin{array}{c}\text { Total } \\
\text { activities }\end{array}$ \\
\hline G1 & $\begin{array}{c}81.24 \\
\pm \\
4.46^{\mathrm{b}}\end{array}$ & $\begin{array}{c}18.76 \\
\pm \\
4.46^{b}\end{array}$ & $\begin{array}{c}33.51 \\
\pm \\
3.70^{b}\end{array}$ & $\begin{array}{c}19.72 \\
\pm \\
2.50^{b}\end{array}$ & $\begin{array}{c}6.48 \\
\pm \\
2.00^{b}\end{array}$ & $\begin{array}{c}9.12 \\
\pm \\
3.03^{\mathrm{b}}\end{array}$ & $\begin{array}{c}6.45 \\
\pm \\
1.32\end{array}$ & $\begin{array}{c}3.87 \\
\pm \\
1.09^{\mathrm{b}}\end{array}$ & $\begin{array}{c}2.48 \\
\pm \\
0.54\end{array}$ & $\begin{array}{c}12.80 \\
\pm \\
2.90^{\mathrm{b}}\end{array}$ \\
\hline G2 & $\begin{array}{c}10.80 \\
\pm \\
4.22^{c}\end{array}$ & $\begin{array}{c}89.20 \\
\pm \\
4.22^{\mathrm{a}}\end{array}$ & $\begin{array}{c}31.67 \\
\pm \\
4.29^{\mathrm{b}}\end{array}$ & $\begin{array}{c}26.72 \\
\pm \\
7.90^{\mathrm{a}}\end{array}$ & $\begin{array}{c}1.40 \\
\pm \\
0.41^{\mathrm{c}}\end{array}$ & $\begin{array}{c}2.19 \\
\pm \\
0.83^{\mathrm{c}}\end{array}$ & $\begin{array}{c}4.48 \\
\pm \\
0.95\end{array}$ & $\begin{array}{c}1.25 \\
\pm \\
0.80^{b}\end{array}$ & $\begin{array}{c}5.23 \\
\pm \\
1.21\end{array}$ & $\begin{array}{c}10.96 \\
\pm \\
2.26^{b}\end{array}$ \\
\hline G3 & $\begin{array}{c}97.26 \\
\pm \\
1.39^{\mathrm{a}}\end{array}$ & $\begin{array}{c}2.74 \\
\pm \\
1.39^{c}\end{array}$ & $\begin{array}{c}47.62 \\
\pm \\
3.17^{\mathrm{a}}\end{array}$ & $\begin{array}{c}2.31 \\
\pm \\
0.52^{c}\end{array}$ & $\begin{array}{c}12.16 \\
\pm \\
2.33^{\mathrm{a}}\end{array}$ & $\begin{array}{c}16.44 \\
\pm \\
2.99^{\mathrm{a}}\end{array}$ & $\begin{array}{c}4.50 \\
\pm \\
0.69\end{array}$ & $\begin{array}{c}12.88 \\
\pm \\
2.76^{\mathrm{a}}\end{array}$ & $\begin{array}{c}3.72 \\
\pm \\
1.30\end{array}$ & $\begin{array}{c}21.06 \\
\pm \\
2.61^{\mathrm{a}}\end{array}$ \\
\hline
\end{tabular}

Results are expressed as means \pm standard error (S.E.)

$\mathbf{a , b , c}$ superscript within the column indicates significant difference at $\mathrm{p}<0.01$

Table 2. Assessment of transportation stress in camels by using haematological measures

\begin{tabular}{|c|c|c|c|c|c|c|c|c|c|c|}
\hline \multirow[t]{2}{*}{ Groups } & \multicolumn{2}{|c|}{ PCV\% } & \multicolumn{2}{|c|}{$\begin{array}{c}\text { RBCs } \\
\text { count } \times 10^{6} / \mu l\end{array}$} & \multicolumn{2}{|c|}{$\begin{array}{c}\text { WBCs count } X \\
10^{3} / \mu l\end{array}$} & \multicolumn{2}{|c|}{$\begin{array}{c}\text { Neutrophil X } \\
10^{3} / \mu l\end{array}$} & \multicolumn{2}{|c|}{$\begin{array}{c}\text { Lymphocyte } X \\
10^{3} / \mu l\end{array}$} \\
\hline & T0 & T18 & T0 & T18 & T0 & T18 & T0 & T18 & T0 & T18 \\
\hline G1 & $\begin{array}{c}38.18 \\
\pm \\
0.60^{\mathrm{a}}\end{array}$ & $\begin{array}{c}39.70 \\
\pm \\
0.60^{\mathrm{ab}}\end{array}$ & $\begin{array}{c}8.67 \\
\pm \\
0.17^{\mathrm{a}}\end{array}$ & $\begin{array}{c}8.29 \\
\pm \\
0.25^{\mathrm{a}}\end{array}$ & $\begin{array}{c}20.7 \\
2 \\
\pm \\
1.03^{\mathrm{a}}\end{array}$ & $\begin{array}{c}16.43 \\
\pm \\
0.89^{\mathrm{ab}}\end{array}$ & $\begin{array}{c}14.3 \\
2 \\
\pm \\
0.78^{\mathrm{a}}\end{array}$ & $\begin{array}{c}11.33 \\
\pm \\
0.66^{\mathrm{a}}\end{array}$ & $\begin{array}{c}5.18 \\
\pm \\
0.38^{b}\end{array}$ & $\begin{array}{c}4.10 \\
\pm \\
0.48^{\mathrm{b}}\end{array}$ \\
\hline G2 & $\begin{array}{c}38.0 \\
6 \\
\pm \\
1.13 \\
\mathrm{a}\end{array}$ & $\begin{array}{c}35.76 \\
\pm \\
1.21^{b}\end{array}$ & $\begin{array}{c}7.60 \\
\pm \\
0.23^{b}\end{array}$ & $\begin{array}{c}7.71 \\
\pm \\
0.25^{b}\end{array}$ & $\begin{array}{c}12.93 \\
\pm \\
0.78^{b}\end{array}$ & $\begin{array}{c}12.94 \\
\pm \\
0.74^{\mathrm{b}}\end{array}$ & $\begin{array}{c}9.18 \\
\pm \\
1.12^{\mathrm{c}}\end{array}$ & $\begin{array}{c}8.45 \\
\pm \\
0.35^{b}\end{array}$ & $\begin{array}{c}3.62 \\
\pm \\
0.42^{c}\end{array}$ & $\begin{array}{c}3.90 \\
\pm \\
0.64^{\mathrm{b}}\end{array}$ \\
\hline G3 & $\begin{array}{c}32.92 \\
\pm \\
1.69^{\mathrm{b}} \\
\end{array}$ & $\begin{array}{c}28.00 \\
\pm \\
0.95^{\mathrm{c}} \\
\end{array}$ & $\begin{array}{c}8.64 \\
\pm \\
0.16^{\mathrm{a}} \\
\end{array}$ & $\begin{array}{c}8.59 \\
\pm \\
0.27^{\mathrm{a}} \\
\end{array}$ & $\begin{array}{c}21.73 \\
\pm \\
1.13^{\mathrm{a}} \\
\end{array}$ & $\begin{array}{c}18.30 \\
\pm \\
1.12^{\mathrm{a}}\end{array}$ & $\begin{array}{c}11.06 \\
\pm \\
0.73^{\mathrm{b}}\end{array}$ & $\begin{array}{c}9.61 \\
\pm \\
0.89^{b}\end{array}$ & $\begin{array}{c}7.1 \\
\pm \\
5.47^{\mathrm{a}}\end{array}$ & $\begin{array}{c}6.92 \\
\pm \\
0.72^{\mathrm{a}} \\
\end{array}$ \\
\hline
\end{tabular}

Results are expressed as means \pm standard error (S.E.)

a,b,c superscript within the column indicates significant difference at $\mathrm{p}<0.01$

Table 3. Assessment of transportation stress in camels by using some blood measures

\begin{tabular}{|c|c|c|c|c|c|c|c|c|c|c|}
\hline \multirow[t]{2}{*}{ Groups } & \multicolumn{2}{|c|}{ Total Proteins g/dl } & \multicolumn{2}{|c|}{ Albumin $\mathrm{g} / \mathrm{dl}$} & \multicolumn{2}{|c|}{ Globulin $\mathrm{g} / \mathrm{dl}$} & \multicolumn{2}{|c|}{ Glucose mg/dl } & \multicolumn{2}{|c|}{ Cortisol level $\mu \mathrm{g} / \mathrm{dl}$} \\
\hline & T0 & T18 & T0 & T18 & T0 & T18 & T0 & T18 & T0 & T18 \\
\hline & 10.64 & 9.14 & 4.57 & 4.74 & 6.07 & 4.40 & 120.31 & 116.39 & 17.21 & 6.14 \\
\hline G1 & $\begin{array}{c} \pm \\
0.54^{\mathrm{a}}\end{array}$ & $\begin{array}{l} \pm \\
0.54^{\mathrm{a}}\end{array}$ & $\begin{array}{c} \pm \\
0.13^{\mathrm{a}}\end{array}$ & $\begin{array}{c} \pm \\
0.47^{\mathrm{a}}\end{array}$ & $\begin{array}{c} \pm \\
0.33^{\mathrm{a}}\end{array}$ & $0.55^{\mathrm{b}}$ & $5.54^{\mathrm{a}}$ & $\begin{array}{c} \pm \\
5.36^{\mathrm{b}}\end{array}$ & $\begin{array}{c} \pm \\
2.96^{\mathrm{a}}\end{array}$ & $\stackrel{ \pm}{ \pm}$ \\
\hline & 8.81 & 9.67 & 4.35 & 3.93 & 4.46 & 5.74 & 88.42 & 99.24 & 3.28 & 3.05 \\
\hline G2 & $\begin{array}{c} \pm \\
0.21^{\mathrm{b}}\end{array}$ & $\begin{array}{c} \pm \\
0.71^{\mathrm{a}}\end{array}$ & $\begin{array}{c} \pm \\
0.16^{\mathrm{a}}\end{array}$ & $\begin{array}{c} \pm \\
0.14^{\mathrm{b}}\end{array}$ & $\begin{array}{c} \pm \\
0.15^{\mathrm{b}}\end{array}$ & $\begin{array}{c} \pm \\
0.15^{\mathrm{a}}\end{array}$ & $\stackrel{ \pm}{ \pm .81^{\mathrm{b}}}$ & $\begin{array}{c} \pm \\
3.50^{\mathrm{c}}\end{array}$ & $\begin{array}{c} \pm \\
0.46^{\mathrm{b}}\end{array}$ & $\begin{array}{c} \pm \\
0.27^{\mathrm{b}}\end{array}$ \\
\hline G3 & $\begin{array}{c}7.49 \\
\pm \\
0.40^{b}\end{array}$ & $\begin{array}{c}6.79 \\
\pm \\
0.30^{b}\end{array}$ & $\begin{array}{c}3.85 \\
\pm \\
0.12^{b}\end{array}$ & $\begin{array}{c}3.12 \\
\pm \\
0.22^{b}\end{array}$ & $\begin{array}{c}3.64 \\
\pm \\
0.49^{b}\end{array}$ & $\begin{array}{c}3.67 \\
\pm \\
0.50^{b}\end{array}$ & $\begin{array}{c}134.89 \\
\pm \\
10.22^{\mathrm{a}}\end{array}$ & $\begin{array}{c}155.00 \\
\pm \\
10.70^{\mathrm{a}}\end{array}$ & $\begin{array}{c}3.35 \\
\pm \\
0.38^{b}\end{array}$ & $\begin{array}{c}2.9 \\
\pm \\
0.21^{\mathrm{b}}\end{array}$ \\
\hline
\end{tabular}

Results are expressed as means \pm standard error (S.E.)

a,b,c superscript within the column indicates significant difference at $\mathrm{p}<0.01$ 


\section{DISCUSSION}

Transportation represents a short term welfare problem which constitutes multiple stressors upon animals during long transportation. These include removal from the home environment, loading and unloading, confinement, fasting, water deprivation, social mixing, forced physical exercise, handling, noise and vibration (Warris, 1990 and Grigor et al., 2001). Moreover, camels are subjected to stress during their collection from different areas in Sudan before coming to Egypt.

\section{Behavioural measures}

Behaviour is considered as one of the most important mechanisms of adaptation to stress (Adenkola and Ayo, 2010). Generally, there is a lack of published data about the behavioural adaptation of the dromedary camel to transportation stress either during the journey or after arrival. So we will depend upon the literature cited by different authors on the effect of transportation stress on ruminants in the discussion of such results.

\section{Comfort behaviour}

The current results concerning comfort behaviour were in agreement with that obtained by Atkinson (1992) who mentioned that animals subjected to road transportation stress spent much of the time lying down during and immediately after the journey and Eicher (2001) who found that transported cattle lie more during the recovery period after transportation. These results indicated the marked demand of the animal for comfort (recumbency) on the expense of other maintenance behaviour after exhausting long journey. In general transported camels are exposed to severe exhaustion due to transportation for long time especially by walk transportation. While travelling by trucks camels stood for a longer period of time. Palme et al. (2000) identified that the most stressful part of transportation is being confined in a moving truck. So events before and after travelling is not the primary concern for the animal, it is what goes on during the journey. This may include the stress of not having room to lie down on the truck on a long journey, or not being able to get up again if an animal falls down, which is mainly relating to stocking densities.

\section{Ingestive behaviour}

Concerning the decrease in time budget of ingestive behaviour in transported camels, similar results are reported by Aoyama et al. (2003) who observed a decrease in ingestive behaviour of transported goats. Moreover, Bekele et al. (2011) found that feeding-related behaviours were decreased as dehydration became more severe in the camels which may result from the long journey especially when there is no or little stop for feeding and drinking.

\section{Eliminative behaviour}

The decrease in eliminative behaviour either defaecation or urination in truck and walk agreed with that reported by Bekele et al. (2011) who found that feeding-related behaviours decreased as dehydration became more severe in the camels but disagree with that noted by Ekesbo (2011) and Aradom (2013) who found an increase in the frequency of elimination in transported cattle. It worth mentioning that there is an increase in the frequency of defaecation and urination at the beginning of the journey which may be due to stressful fear but this will decrease gradually as the animal adjust and with time the faeces become dry and scanty (Fraser and Broom, 1990). The decrease in the frequency of defaecation and urination after arrival may be attributed to the decrease or lack of feeding and watering during the exhausting long journey which may be associated with dehydration, haemoconcentration and decreased gut activity.

\section{Body care behaviour}

Regarding body care behaviour, the diminished scratching and total body care activity may be related to stress of transportation and exhaustion of camels because the behavioural changes are considered as the first sign of diseases and main sign of distress (Ayo et al., 2002). Selfgrooming behaviour is considered as one of the signs of health and vitality in animals (Alcock, 1989) and its lowered frequency or absence may indicate the presence of exhaustion, stress or disease. Generally, there is a difficulty in interpretation of the measurements used for assessing the amount of stress and suffering of the animals during the process of transportation (Grandin, 1997 and Scope et al., 2002).

\section{Haematological measures Packed cell volume (PCV)}

The current results of PCV value at $\mathrm{T} 0$ and T18 were in the same concert of prior researches reporting an increase in PCV \% at different times of the journey (Knowles, 1995; Tadich et al., 2005 and Parker et al., 2007). Moreover, Ferlazzo et al. (1993) found that PCV was increased in horses after the journey. On the contrary, other studies showed that PCV was decreased at zero time after loading (Broom et al., 1996) or following 9-14 $\mathrm{h}$ journeys (Knowles et al., 1993). The increase in PCV after the end of journey at T0 and T18 may suggest 
dehydration and haemoconcentration associated with decreased or lack of water intake or splenic contraction induced by sympathetic nerve activity or circulating catecholamines (Knowles, 1995; AlHaidary, 2005; Tadich et al., 2005 and Parker et al., 2007). Transportation combined with fasting for 48-72 $\mathrm{h}$ resulted in high PCV value, thereby demonstrating that the greater state of dehydration is as a result of water turn-over associated with the physical activity during transportation as well as the stress of adjusting to a new environment (Cole et al., 1987; Becker et al., 1989 and Odore et al., 2004). It was observed that PCV value may be increased during handling and loading of animals (Tadich et al., 2005).

\section{RBCs and WBCs counts}

The results of RBCs count are variable which is decreased in camels transported by walk $(\mathrm{G} 2)$ at T0 and T18 that disagreed with previous results indicating that there was an increase in RBCs count in animals during and after transport (Minka and Ayo, 2010 and El Khasmi et al., 2013) and this may be caused by transportation stress resulting from long-term walk (Broom et al., 1996 and Tadich et al., 2005). The increased RBCs count in camels transported by trucks (G1) at T0 and T18 are parallel to that obtained by Minka and Ayo (2010) and El Khasmi et al. (2013). This increase may be related to body dehydration (Plyashenko and Sidorov, 1987 and New et al., 1996) or due to acute exposure of animals to stressful stimulation is attended by a significant activation of the sympathetic-adrenal medullary system, including increased synthesis, circulating levels and release of catecholamines into the circulation resulting in splenic contraction and the release of RBC into the circulation (McCarty et al., 1988).

It was observed that there was a significant decrease in WBCs count in G2 of camels which may be attributed to transportation stress as reported in early studies (Sundaresan et al., 1990, Broom et al., 1996 and Tadich et al., 2005). On the other hand, WBCs count was increased in G1 of camels. Similar findings are presented by Davis et al. (2008) and Minka and Ayo (2010). El Khasmi et al. (2013) found no significant changes in WBCs counts in camels transported under heat condition. As previously mentioned in RBCs count the increase in WBCs count may occur in case of dehydration (Plyashenko and Sidorov, 1987 and Nwe et al., 1996) due to long journey with decreased or lack of water intake. AL-Wabel (2010) reported that total WBCs count in camels was not affected by stressful condition of transportation.

\section{Neutrophil and lymphocyte counts}

The results revealed an increase in neutrophil count (neutrophilia) and a decrease in lymphocyte count (lymphocytopenia) in camels transported by trucks which is supported in previous literature (Fraser and Broom, 1990; Ayo et al., 2005 and Minka and Ayo, 2007). AL-Wabel (2010) found that transportation stress had no effect on neutrophil count; however it caused slight reduction in lymphocyte counts in camels.

\section{Blood measures}

Total proteins, albumin and globulin

Transported camels either by trucks or walk had higher values of total proteins, albumin and globulin. These results are parallel to that observed in sheep (Knowles, et al., 1996) and cattle (Knowles et al., 1999 and Parker et al., 2007). These parameters were observed to increase when animals suffer from dehydration as a result of long journeys (Parker et al., 2003). The increase in albumin level during transportation may also suggest the degree of stress that animals encountered during the journey and the response of the animal to such stressors (Krizanovic, et al., 2008 and Powers and Jackson, 2008).

\section{Glucose}

Plasma glucose is one of the physiological measures of transportation stress. The decrease in plasma glucose level in transported camels especially by walk at T0 and T18 agrees with the results reported in cattle and goats (Mormède et al., 1982; Kent and Ewbank, 1983; Kent and Ewbank, 1986a, b; Fraser and Broom, 1990; Nwe et al., 1996; Kannan et al., 2000 and Early et al., 2011) but other studies do not support these findings (Tadich et al., 2005 and Elkhasmi et al., 2013). The decrease in glucose level mainly is a consequence of lack of food during long journey. Most of prior literature indicated that plasma glucose level increased during the first few hours of transportation due to glycogenolysis associated with the increase in catecholamines and glucocorticoids which were released during the stress of transportation (Tadich et al., 2005) but this was not measured in our study.

\section{Cortisol}

The high level of cortisol in camels transported by truck (G1) at T0 and T18 was parallel to the documented literature in different animal subjected to transportation stress (Leadon, 1995; Broom et al., 1996; Warriss et al., 1999; Alberghina et al., 2003; Aoyama et al., 2003; Broom, 2003; Odore et al., 2004; Ndlovu et al., 2008; Werner and Gallo, 2008; Saeb et al. 2010 
and Elkhasmi, et al. 2013). As cortisol levels are highly variable, absolute comparisons between studies should not be made (Grandin 1997). Cortisol is considered as one of the indicator of stress in different animals species even transport is not commencing which reflect the psychological status of animals as well as it is a good index for the reaction of animals to any environmental challenge. Stress imposed on animals during transportation includes exposure of animals to a new environment, handling, loading and the start of vehicle motion (Broom, 2003 and Ndlovu et al., 2008).

\section{CONCLUSION}

The continuous demand for camels' meat recommends their transportation from Sudan to Egypt for long journey which is almost inevitable to compensate this shortage. Generally the majority of livestock in developing countries are moved by trekking on the hoof, by road and rail. Transportation is considered as a short term stressful condition which adversely affects the welfare of camels in addition to its economic impact. Camels can cope to the adverse conditions of long journey of transport by their regulatory systems including behavioural and physiological components to return the body to its resting state. The combination of behavioural, haematological and blood measures is valuable in the assessment of stress during transportation than the use of a single measure which may give erroneous results. Further researches are required on the assessment of transportation stress on camels due to lack of literatures in this subject.

\section{REFERENCES}

ADENKOLA, A.Y., AYO, J.O.2010. Physiological and behavioural response of livestock to road transportation stress: a review. African Journal of Biotechnology 9, 4845-4856.

ALBERGHINA, D., MEDICA,P., FAZIO, E., CAVALERI, S. AND FERLAZZO, A.2003. Effect of long distance road transport on serum cortisol and haematocrit in limousine calves and influence of body weight decrease. Biotechnol. Agron. Soc. Environ. 5: 73-77.

ALCOCK, J. 1989. “Animal Behaviour," 4th ed. Sinauer, Sunderland, MA

AL-HAIDARY, A. 2005. Effect of dehydration on core body temperature of young Arabian camels (Camelus dromedarius). Journal of King Saud University.

AL-WABEL, N.A. 2010. Transportation stress in camels and goats. J.Agric.Vet.Sci., Qassim University. 3(1): 43-48.

AOYAMA M, NEGISHI A, ABE A, MAEJIMA Y, SUGITA S 2003. Sexdifferences in stress response to transportation in goats: effects ofgonadal hormones. Anim. Sci. J. 74: 511-519.
ARADOM, S. 2013. Animal transport and welfare with special emphasis on transport time and vibration. Thesis of PhD, Faculty of Natural Resources and Agricultural Sciences, Swedish University of Agricultural Sciences.

ATKINSON, P.J. 1992. Investigation of the effects of transport and lairage on hydration state and resting behaviour of calves for export. Vet. Rec. 130: 413416.

AYO, J.O., MINKA, N.S., FAYOMI, A. 2005. Effects of ascorbic acid on rectal temperature of pullets transported by road during the hot-dry season in Northern Nigeria. Proc. 10th Ann. Conf. Anim. Sci. Ass. Nig. Ado-Eketi, Nigeria 10: 58-60.

AYO, J. O., OLADELE, S. B., FAYOMI, A. 2002. Behavioural reactions of cattle to stress situations: A review. J. Agric. Technol, 8, 15-20.

BARTHOLOMEW, R.J. AND DELANEY, A.M. 1964. Proc Australian Assoc. clin. Biochem. 1:64.

BECKER, B.A.I., MAYES, H.F., HAHN, G.L., NIENABER, J.A., JEIS, G.W., ANDERSON, M.E., HEYMANN, H.AND HEDRICH, H.B. 1989. Effect of fasting and transportation on various physiological parameters and meat quality of slaughter hogs. J. Anim. Sci. 69: 334-340.

BEKELE, T., LUNDEHEIM, N., DAHLBORN, K. 2011. Milk production and feeding behaviour in the camel (Camelus dromedarius) during 4 watering regimens.Journal of dairy science, 94(3), 1310-1317.

BORELE, E. 2000. Stress and coping in farm animals. Arch. Tierz., Dummerstorf 43 Sonderheft, 144-152.

BROOM, D.M. 2003. Causes of poor welfare in large animal during transport. Vet. Res. Comm. 27: 515518.

BROOM, D.M., GOODE, J.A., HALL, S.J.G., LLOYD, D.M. AND PARROTT, R.F. 1996. Hormonal and physiological effects of a 15-hour road journey in sheep: comparison with the responses to loading, handling and penning in the absence of transport. Br. Vet. J. 152: 593-604.

BURTIS, C.A. AND ASHWEED, E.R. 1994. Textbook of clinical chemistry' 2ndEd.W.B.Saunders Company. Philadelphia,pp. 1825-1827.

COLE, N.A., PHILIPS, W.A. AND HUTCHSON, D.P. 1987. The effect of prefast on transport in calves. J. Anim. Sci. 63: 1015-1020.

DAVIS, A. K., MANEY, D. L., MAERZ, J. C. 2008. The use of leukocyte profiles to measure stress in vertebrates: a review for ecologists. Functional Ecology, 22(5), 760-772.

EARLY, B., MURRAY, M., PRENDIVILLE, D.J., PINTADO, B., BOEQUE, C. AND CANALI, E. 2011. The effect of transport by road and sea on physiology, immunity and behaviour of cattle. Res. Vet. Sci. 92:531-541.

EICHER, S.D. 2001. Transportation of cattle in the dairy industry. Current research and future directions. J. Dairy Sci. 84(E Suppl.): 19-23.

EKESBO, I. 2011. Swine and cattle. In: I Ekesbo, Farm animal behaviour: characteristics for assessment of health and welfare: pp.17-41, 53-81, CAB International, Wallingford, UK. 
EL KHASMI, M., CHAKIR, Y., RIAD, F., SAFWATE, A., TAHIR, E.H., FARH, M. AND EL ABBADI, N., ABOUHAFS, R. AND FAYE, B. 2013. Effects of transportation stress during the hot-dry Season on Some haematological and physiological parameters in Moroccan dromedary camels (Camelus dromedarius), Journal of life sciences, 7:13-25.

ELKHASMI,M.,RAID,F.,SAFWATE,A., TAHRI,E.H., FARH,M. AND ELABBADI,N., ET AL., 2010. Effects of Preslaughter stress on meat quality and prophylactic metabolism in camels (camelus dromedarius ), Journal of camelid science, 3: 3338.

FERLAZZO, A., FERZIO, E., MURANIA, L. AND PICCIONA, G. 1993. Physiological responses of stallions to transport stress. Proc. 3rd Int. Congr. Int. Soc. Appl. Ethol. pp. 544-546.

FRASER, A.F., BROOM, D.B. 1997. Farm animal behaviour and welfare. CAB International, London, UK.

GRANDIN, T.1993. Livestock Handling and Transport. CAB International: Wallingford, UK.

GRANDIN, T. 1997. Assessment of stress during handling and transport. J. Anim. Sci. 75: 249-257.

GRIGOR, PN, COCRAM, MS, STEELE，WB，LE SUEUR, CJ, FORSYTH, RE, GUTHRLE, JA, JOHNSO, AK, SANDILANDS, V, REID, HW, SINCLAR, C, BROWN, HK . 2001. Effects of space allowance during transport and duration of mid-journey lairage period on the physiological, behavioural and immunological responses of young calves during and after transport. Anim Sci 73: 341-360

HURTUNG, J. 2003. Effects of transport on health of farmanimals.VeterinaryResearch Communication 27:525-527.

JAIN, N.C. 1986. Shalm's veterinary hematology. 4th Ed. Lea and Febiger, Philadelphia, U.S.A.

KANNAN, G., TERRILL, T.H., KOUAKOU, B., GAZAL, O.S., GELAYE, S., AMOAH, E.A. AND SAMAKE, S. 2000. Transportation of goats: effects on physiological stress responses and liveweight loss. J. Anim. Sci. 78: 1450-1457.

KENT, J.E. AND EWBANK, R. 1983. Changes in the behaviour of cattle during and after road transportation. Appl. Anim. Ethol., 11:85.

KENT, J.E. AND EWBANK, R. 1986a. The effect of road transportation on the blood constituents and behaviour of calves. II One to three weeks old. Br. Vet. J. 142: 131-140.

KENT, J.E. AND EWBANK, R. 1986b. The effect of road transportation on the blood constituents and behaviour of calves. III Three months old. Br. Vet. J. 142: 326-335.

KNOWLES, T.G. 1995. A review of post-transport mortality among young calves. Vet. Rec. 137: 406-407.

KNOWLES, T.G., BALL, R.C., WARRISS, P.D. AND EDWARDS, J.E. 1996. A survey to investigate potential dehydration in slaughtered broiler chickens. Br.Vet. J.152: 307-314.
KNOWLES, G., WARRISS, P.G. AND BROWN, S.N. 1993. Long distance transport of lambs and the time needed for subsequent recovery. Vet. Rec. 123: 286-293.

KNOWLES, T.G., WARRISS, P.D., BROWN, S.N. AND EDWARDS, J.E. 1999. Effects on cattle of transportation by road for up to 31-hours. Vet. Rec. 145: 575-582.

KRIZANOVIC， D., SUSIC， V., BOZIC， P., STOKOVIC, I. AND EKERT-KABALIN, A. 2008. Changes of bovine lipid peroxides and some antioxidants in the cause of growth. Vet. Arhiv. 78: 269-278.

LEADON, D. 1995. Transport stress and the equine athlete. Eq. Vet. Educ. 7: 253-255.

MASON, G., MENDL, M.1993. Why is there no simple way of measuring animal welfare?. Anim. Welf. 2, 301-319

MARTIN, P. AND BATESON, P. 1993. Measuring Behaviour: An Introductory Guide, 2nd ed. Cambridge University Press. Cambridge, UK.

MCCARTY, R., HORWATT, K. AND KONARSKA, M. 1988. Chronic stress and sympathetic-adrenal medullary responsiveness, Social Science and Medicine 26:333-341.

MINKA, N. S. AND AYO, J. O. 2007. Physiological responses of transported goats treated with ascorbic acid during the hot-dry season. Anim. Sci. J. 78: 164-172.

MINKA, N. S., AYO, O. J. 2010. Serum biochemical activities and muscular soreness in transported goats administered with ascorbic acid during the hot-dry season. European Journal of Translational Myology, 20 (4), 193-203.

MORMÈDE, P., SOISSONS, J., BLUTHÉ, R., RAOULT, J., LEGARFF, G., LEVIERAX, D. AND DANTZER, R. 1982. Effects of transportation on blood serum composition, disease incidence and production traits in young calves. Influence of the journey duration. Annls Rech . Vét., 13: 369-384.

NDLOVU, T., CHIMONYO, M., OKON, A.I. AND MUCHENJE, V. 2008. A comparison of stress hormone concentrations at slaughter in Nguni, Bonsmara and Angus steers. Afr. J. Agric. Res. 3: 96-100.

NWE,T.M., HORI, E, MANDA, M. AND WATANABE, S. 1996. Significance of catecholamines and cortisol levels in blood during transportation stress in goats. Small Anim. Res. 20: 129-135.

ODORE, R., D'ANGELO, A., BADINO, P., BELLINO, C., PAgliasso, S. AND RE, G. 2004. Road transportation effects blood hormone levels and lymphocyte glucocorticoid and B-adrenergic receptor concentrations in calves. Vet. J. 168: 297-303.

PALME, R., ROBIA, C., BAUMGARTNER, W., MØ STL, E. 2000. Transport stress in cattle as reflected by an increase in faecal cortisol metabolite concentrations. Vet. Rec. 146, 108109. 
PARKER, A.J., DOBSON, G.P. AND FITZPATRICK, L. A. 2007. Physiological and metabolic effects of prophylactic treatment with the osmolytes glycerol and betaine on Bos indicus steers during long duration transportation. J. Anim. Sci. 85: 2916-2923.

PARKER, A.J., HAMLIN, G.P., COLEMAN, C.J. AND FITZPATTRICK, L.A. 2003. Quantitative analysis of acid base balance in Bos indicus steers subjected to transportation of long duration. J. Anim. Sci. 81: 1434-1439.

PLYASCHENKO, S.I. AND SIDOROV, V.T. 1987. Stresses in Farm Animals. Agropromizdat, Moscow (in Russian).

POWERS, S.K. AND JACKSON, M.J. 2008. Exerciseinduced oxidative stress: Cellular mechanisms and impact on muscle force production. Physiol. Rev. 88: 1243-1276.

SAEB , M. , BAGHSHANI .S. , NAZIFI . S. AND SAEB .S. 2010. Physiological response of dromedary camels to road transportation in relation to circulating levels of cortisol, thyroid hormones and some serum biochemical parameters. Trop Anim Health Prod , 42: 55-63.

SHALAH, M.R. 1983. The role of camels in overcoming world meat shortage. Egyptian J. Vet. Sci., 20:101-110.

SCHALM, O.W., JAIN, N.C. AND CARROL, E.J. 1975. Veterinary Hematology, Third Edition pp 807. Lea and Febiger: Philadelphia, USA

SCOPE FILIP, T., GABLER, C. AND RESCH, F. 2002. The influence of stress from transport and handling: hematological and clinical chemistry blood parameters of racing pigeon (columbia liva domestica). Avian Dis. 46: 224-229.

SUNDARESAN, G., SUTHANTHIRARAJAN, N., \& NAMASIVAYAM, A. 1990. Certain immunological parameters in subacute cold stress. Ind. J. Physiol, 34, 51-60.

TADICH, N., GALLO, H., BUSTAMANTE, H., SCHWERTER, M. AND VAN SCHAIK, G. 2005. Effects of transport and lairage time on some blood constituents of Friesian-Cross steers in Chile. Livest. Prod. Sci. 93: 223-233.

WARRIS, P.D. 1998. The welfare of slaughter pigs during transport. Anim Welfare 7: 365-381.

WEISSMAN, N., SCHOENBACH, E.B., ARMISTEAD, E.B. 1950. J Biol Chem187:153, 1950.

WERNER, M. AND GALLO, C. 2008. Effect of transport, lairage and stunning on the concentrations of some blood constituents in horses destined for slaughter. Livestock Sci. 115: 94-98.

YAGIL,R.1982. Camels and Camel Milk. FAO Animal Production and Health. Publications Division, Food and Agriculture Organization of the United Nations. Via delleTerme di Caracalla, 00100 Rome, Italy,26.

YOUSIF,O.K,BABIKER,S.A.1989. The desert camel as meat animals. MeatSci. 26: 245-254. Cited by Nazifi,S.et al (2009).

ZAPATA, B., GIMPEL, J., BONACIC, C., GONZALEZ, B.A., RIVEROS, J.L.,
RAMIREZ, A.M., BAS, F. AND MACDONALD ,D.W.2004. The effect of transport on cortisol, glucose, heart rate, leukocytes and body weight in captive-reared guanacos (Lama guanicoe), Anim. Welf., 13: 439444.

ZILVA, J.F. AND PANNALL, P.R. 1979. Carbohydrate metabolism in "Clinical chemistry in diagnosis and treatment". lioyd-luke London 1979, chap. 9:174-214. 